\title{
Uma Atriz do Cinema Brasileiro: entrevista com Dira Paes
}

\section{A Brazilian film actress: an interview with Dira Paes}

Entrevista com Dira Paes concedida à

Virgínia Jorge ${ }^{1}$ 


\section{Resumo}

A atriz brasileira Dira Paes tem em sua filmografia 36 filmes em 33 anos de carreira. É difícil, a partir de sua estreia em 1985, encontrar um ano em que Dira Paes não tenha se dedicado a atuar no cinema nacional. Tamanha constância e dedicação fazem de Dira Paes uma testemunha viva da nossa cinematografia nas ultimas três décadas. Nesta entrevista, concedida à professora e pesquisadora Virgínia Jorge, em junho de 2017, no contexto de sua tese de doutorado "Vivência Laboratorial e Mise en scéne - Os espaços de preparação do ator enquanto lócus de produção de sentidos, afetos e relações de trabalho no cinema brasileiro contemporâneo", Dira fala sobre sua larga trajetória e reflete sobre as transformações pelas quais passa a atuação no cinema nacional.

Palavras-chave: Dira Paes; Cinema brasileiro; preparação do ator

\section{Abstract}

The Brazilian actress Dira Paes has done 36 feature films in 33 years of acting. Since her debut in 1985, it is hard to find a year in which Dira Paes did not worked in the Brazilian cinema. Such constancy and dedication makes Dira Paes an important witness of our national cinema in the three last decades. In this interview by the professor and researcher Virginia Jorge in June of 2017 for her doctoral dissertation: "Acting Investigation and Mise èn Scene The spaces of actor preparation as locus of meaning, emotions and work relations in contemporary Brazilian cinema", Dira talks about her long career in cinema acting and contemplate the ongoing changes in film acting in Brazilian contemporary scenario.

Keywords: Dira Paes; Brazilian cinema; preparation of the actor 


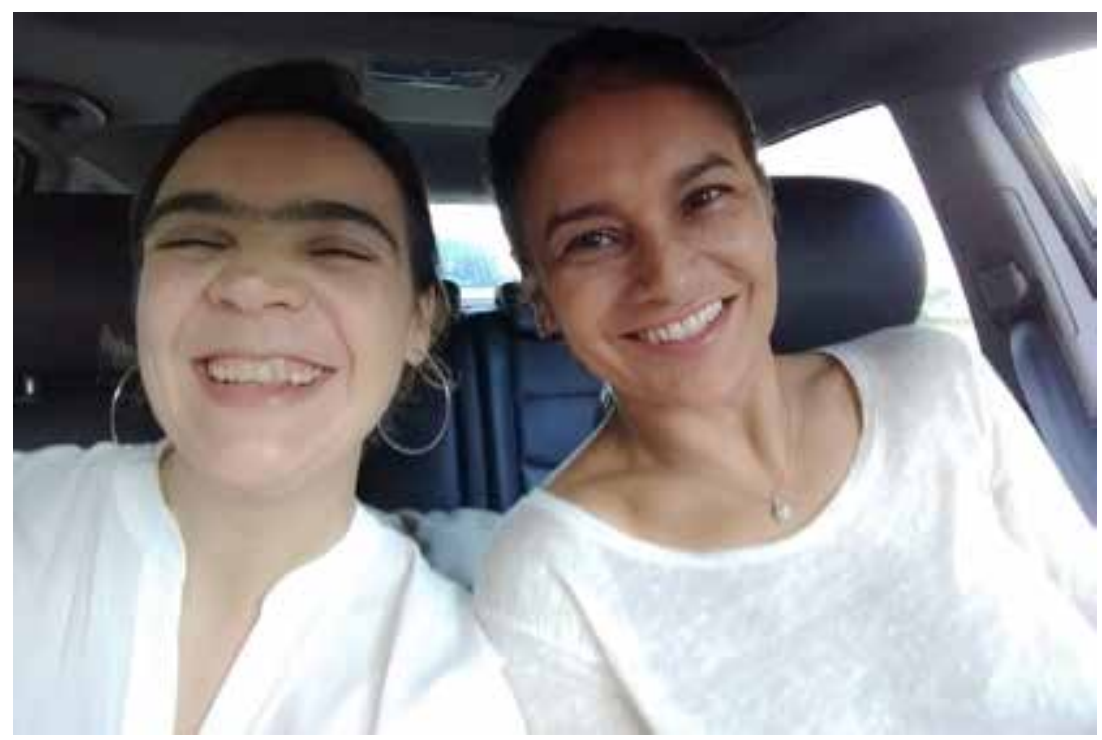

Virgínia Jorge e Dira Paes - Selfie no dia da entrevista

A atriz brasileira Dira Paes tem em sua filmografia 36 filmes em 33 anos de carreira. É difícil, a partir de sua estreia em 1985, encontrar um ano em que Dira Paes não tenha se dedicado a atuar no cinema nacional. Tamanha constância e dedicação fazem de Dira Paes uma testemunha viva da nossa cinematografia nas ultimas três décadas. Nesta entrevista, concedida à professora e pesquisadora Virgínia Jorge, em junho de 2017, no contexto de sua tese de doutorado "Vivência Laboratorial e Mise en scéne - Os espaços de preparação do ator enquanto lócus de produção de sentidos, afetos e relações de trabalho no cinema brasileiro contemporâneo", Dira fala sobre sua larga trajetória e reflete sobre as transformações pelas quais passa a atuação no cinema nacional.

Ecleidira Maria Fonseca Paes - Dira Paes - nasceu 30 de junho de 1969, na cidade de Abaetetuba, interior do Pará. Sua estreia no cinema se deu em 1985, aos 14 anos, na obra $A$ Floresta das Esmeraldas, uma produção inglesa e ambientada no Brasil, com direção de John Boorman. No ano de 1987 com o desejo de investir em sua carreira artística, Dira Paes se mudou para o Rio de Janeiro, então com 18 anos. Neste ano participa do filme Ele, o Boto com direção de Walter Lima Jr. No Rio de Janeiro se formou em Artes Cênicas pela UNIRIO, estudou francês e fez cursos paralelos como o de expressão corporal, conforme seus personagens exigiam. Chegou, também, a cursar por dois anos Filosofia, mas não se graduou. Em 1990 foi contratada pela TV Globo e passou a integrar o elenco de vários programas e novelas desta emissora. Além de, com muita frequência no cinema e na televisão, Dira Paes também vivenciou as experiências do palco.

Viajou pelo Brasil durante três anos, a partir de 1992, com a montagem de Capitães da Areia, de Jorge Amado, dirigida por Roberto Bomtempo. Mais tarde, fez $O$ Avarento (2000), de Molière, com direção de Amir Haddad, e trabalhou com a Cia dos Atores em Meu Destino É Pecar (2002), de Nelson Rodrigues, peça com a qual também correu o país ${ }^{2}$.

${ }_{2}^{2}$ Depoimento de Dira Paes ao Memória Globo em 06/03/2017. Fonte: http://memoriaglobo.globo.com/perfis/profissionais/dira-paes/dira-paes-trajetoria.htm. Acesso em: 20 abr. 2018. 
Em março de 1990, no início do equivocado governo de Fernando Collor, a Embrafilme foi encerrada, e com ela o financiamento de inúmeros projetos cinematográficos nacionais. A retomada do cinema nacional ocorreu a partir de 1996, com as leis de incentivo a cultura e o apoio da FUNARTE. Neste ano Dira Paes participa do filme Corisco \& Dadá, de Rosemberg Cariry. Com esta personagem ela ganhou o premio de Melhor atriz, no Festival de Brasília, o primeiro de uma serie de prêmios que coleciona ao longo de sua carreia cinematográfica. Sobre sua intensa produção no cinema, Dira Paes aponta o seguinte aprendizado:

Os convites foram incríveis, diversos para vários lugares do Brasil. Faço um filme no Rio Grande do Sul, em Brasília, Pernambuco, no Ceará, volto para Brasília. Então eu tive essa brasilidade de entender que o Brasil é muito imenso e que eu posso fazer parte de todos esses "brasis"3.

Então, a opção por te procurar para essa entrevista surge primeiro, claro, por uma paixão pelo seu trabalho, e segundo, porque a minha pesquisa é sobre essa série de transformações que eu vejo acontecendo no cinema brasileiro nos últimos anos e é muito difícil achar atrizes e atores com a constância que você tem no cinema brasileiro nos últimos 20, 30 anos. Então, eu acho que a sua contribuição vai ser muito rica, no sentido de, principalmente, me dizer se você vê mudanças de quando você começou. Como foi esse seu começo. Se você vê mudanças agora, principalmente no trabalho dos atores e atrizes e na relação desses atores e atrizes com a equipe, com a direção. Também com relação aos ensaios, se tem mais ensaios do que antes, se esses ensaios têm naturezas diferentes.... Enfim, por enquanto, assim, bem aberto mesmo...

É, a gente está falando de 33 anos, né? Eu vou te falar que, realmente, agora você me propondo essa reflexão, eu passei acho que por vários e os mais diversos momentos. Não só falando de uma questão de tempo, mas uma questão da diversidade das propostas dos diretores com os quais eu tive a oportunidade de trabalhar. $E$ aí eu vou começar meio cronologicamente esse raciocínio. Quando eu comecei, eu fui uma atriz de intuição, apesar de ter uma atividade na escola, que já eram impulsos de interpretação que eu não sabia que eu tinha. Como ser a porta-voz da classe, como propor para o professor de literatura para que a gente encenasse os livros, inspirados nos livros que ele propunha e não só fazer redação, ou seja, e com isso alguns alunos também gostavam da ideia e me acompanhavam. A maioria queria fazer só redação e parar. E eu tenho lembranças bem criativas dessa época. A gente está falando de quando eu tinha 14, 15 anos. Nisso chega a trupe do The Emerald Forest lá no Pará e um professor de arte, que não era meu professor, que é um grande ator paraense que é o Cláudio Barros, que descobriu as Tainás, assessorou pessoalmente na vida delas, e tal, dos filmes Tainá ... Ele falou: tem uma equipe da Embassy Pictures aqui, procurando atrizes, com seu tipo, vai lá, você é tão "nãnãnã"... E eu já totalmente direcionada, porque eu faço aniversário sexta-feira, inclusive, dia 30. E aí eu estava com 15 anos. E na virada do ano eu liguei e eles falaram para eu ir lá. José Possi Neto 
faz uma foto minha, fala que eu tenho uma cara boa. E em janeiro eu fui chamada para ir lá fazer um teste, e nesse teste, que foi um teste de olhar no primeiro momento, o diretor já me selecionou, que era o John Boorman. Quem estava traduzindo era o Flávio Tambellini e depois ele selecionou cinco meninas para fazer o teste de vídeo, e propôs uma improvisação com ritmos. E isso foi um começo, uma experiência que eu não tinha tido, já naquele teste, que era o ritmo dos tambores, sopros, ritmos de floresta, do Junior Homrich que era o músico que acompanhava os testes, e o ritmo, ele me trouxe..., sabe quando parece que você encontrou a sua casa? Assim..., aquilo me causava como se fosse assim um certo... uma falta de timidez. Eu não ficava encabulada, a música me deixava muito a vontade. Eu já sou uma pessoa que consigo, não é que eu não seja tímida, mas eu consigo me comportar e disfarçar muito bem publicamente os meus por dizer..., as coisas que estão guardadas comigo, os meus segredos. E aí falando do Floresta, quando eu soube que, aí ele fez alguns outros testes, ele estava testando também os meninos, e aí eu soube que eu ia ser a atriz principal do filme, feminino né, principal personagem feminino. E eu com 15 anos. Eu faço o filme com 15 anos...

E a preparação do Floresta das Esmeraldas foi a melhor porta de entrada que eu poderia ter, porque foi tudo muito "cinderelesco", era tudo muito grande, era uma atenção muito grande a mim, por ser menor de idade, pelo controle de alimentação, eu tinha que me alimentar de 4 em 4 horas. Eu tinha que ter todo uns cuidados.

Mas, falando da preparação foi muito peculiar porque eu era a única menina, com 40 homens no Shopping da Gávea, que iam fazer os índios, 20 de uma tribo e 20 de outra tribo, e eu tinha que ter essa, vamos dizer, já não tinha essa diferença de gênero nos ensaios, mas tinha um aspecto que era o volume dos homens, então o volume dos homens impressionava um pouco, mas todos vestidos; passamos fazendo comportamento, o que seria o comportamento cênico dos índios, postura, arco e flecha, tivemos preparação... Era um filme que tinha equipes do mundo inteiro. Eram atores, bailarinos, não eram índios verdadeiros. Atores e bailarinos. E aí teve uma coisa muito incrível, que aquilo foi me dando, assim eu sei lá, eu fui me dando importância. Fiquei metida, no bom sentido da palavra. Descobri que eu era bonita. Eu era virgem, era uma menina sem contato com a sexualidade e me mantive assim durante todo o filme, com a minha mãe do lado, sendo uma observadora muito próxima de tudo. Mas minha mãe nunca foi uma pessoa muito repressora, sabe, nem meu pai. Tanto é que tem uma coisa bem legal, que, quando eu recebi a notícia que eu iria fazer o papel principal do filme, o meu pai, a família toda reunida, eu lembro que ele falou assim: "a única coisa que eu me preocupo é: você vai conseguir conviver com os colegas do colégio depois que esse filme estrear?" Sabe, eu falei: "nunca tinha pensado nesse aspecto". E eu falei para ele que sim. E ele falou: "por mim pode fazer". Eu falei pai: "eu vou ficar nua". E ele disse: "Se você diz que consegue...". Para um homem que era... eu achei tão a frente do tempo dele, todo mundo falou de várias questões, e a dele era só essa: se eu conseguiria conviver depois do filme com aquela realidade. E durante esse preparo eu me descobri menina-mulher, mas eu era muito menina. Muito menina, olhando para trás. E isso me deu uma blindada daquela testosterona pulsante que tinha nesses ensaios. Tinha um momento em que ficava todo mundo junto e depois ficava só eu e o Charlie Boorman, que era filho do diretor e que fazia o 
papel do mocinho, vamos assim dizer. Isso a gente fez durante um mês, no Shopping da Gávea, numa sala. As coordenadas pelo José Possi Neto, e tinha o João e a Mazé, que eram os assistentes, bailarinos, acostumados a trabalhar com atores.

\section{Então a preparação foi feita por eles?}

Foram testes né, a admissão de todos foi através de testes. Porque eu lembro que o Maurício Mattar não passou. Tinha uma coisa assim de pessoas que ficaram famosíssimas e que não tinham feito o filme. E aí teve um segundo momento desse trabalho, que foi na locação. Então a gente se desloca em fevereiro, pra Paraty, um filme que durou 6 meses, coisas que não existem mais. Toda a equipe se desloca para Paraty, em Paraty, a gente começou a ter já uma preparação mais realista, porque a gente já estava nos cenários, a gente começa um tempo ali de roupa, depois tira a roupa todo mundo, então aí teve um ritual, que foi muito bonito, mas foi a primeira vez, por exemplo, que eu vi um órgão masculino. Eu não vi um, eu vi 45 ao mesmo tempo. Que estreia, que loucura. E eu e a minha mãe fazíamos comentários específicos, porque eu acho que nem ela tinha tido essa visão, maravilhosa, em roda, em círculo. Teve esse momento de abstração do que era seu, então eu começo a minha vida como atriz, tendo que me despir literalmente. E sendo uma menina, eu não quero falar pura, mas é. [...] eu acho interessante, porque você tem um despertar da sua sexualidade, mas sem praticar a sexualidade, é muito bonito isso, eu acho. Eu tive a oportunidade de viver isso. E eu realmente vivi para o filme onde eu não tive envolvimento com ninguém, então aquilo me manteve convivendo com o universo masculino, isso me manteve de um foco e ao mesmo tempo desabrochar que eram contraditórios e deram super certo. E em mim, que eu te falei brincando, provocou esse empoderamento, mas é que eu tinha uma responsabilidade, então eu acho que naturalmente a minha inteligência emocional fez com que eu trouxesse essa coluna ereta, você veja, eu já cresci para poder falar disso, entendendo a linguagem desse meu cotidiano né, entender o que eles queriam de mim e o que eu queria dar. Eu estou fazendo essa introdução, porque depois começa o filme, e eu não lembro de interpretar. Era como se aquilo tivesse tão... claramente assim, a chave do action, dentro do que ... e a personagem também. Não que eu fosse uma índia, nem era uma menina... a gente tem uma vida super urbana. Eu não tinha esse contato também, estava aprendendo ali. Foram muitos desafios, porque era um filme que não era um filme existencialista, era um filme de aventura, então era um filme que tinha uma postura física, era um filme que tinha uma sedução natural, e era um filme que não tinha o meu habitat natural. Então aquilo tudo foi se misturando, mas a gente teve um tempo tão grande do que a gente ia fazer, do jeito que a gente ia ser conduzidos, que as coisas fluíram de uma maneira muito positiva, muito mesmo.

\section{Quanto tempo foi essa preparação até chegar nas filmagens? E os ensaios, como eram conduzidos os ensaios?}

Três meses. Janeiro, fevereiro e março. Começou em março. Muitos exercícios de corpo no começo, aí entra música. Exercícios de alongamento, depois ritmo e 
corpo, depois uma tribo pra lá e outra tribo pra lá, "uh uh uh uh", sons, e postura. $E$ mulheres, como é que as mulheres, como é que você senta, a postura, a questão postural. E depois contracena, como se fosse, depois que você está aquecida, aí você tem um momento de contracenar.

\section{Quem conduzia? O diretor, ou eram outras pessoas?}

José Possi Neto, diretor de teatro, com dois assistentes. E a preparação só tinha o olhar da direção geral, que aí o Boorman tinha o próprio assistente dele que era o Berry Levinson. Por exemplo, os maquiadores iam testando na gente até decidir qual era a minha maquiagem, qual era a minha pintura. Eu raspei as sobrancelhas, então teve essas intervenções físicas que ajudam muito o ator em todos os momentos, porque você dá uma coisa que é, ou dá ou tira, uma coisa que é sua, para absorver outro perfil que não é o seu. Ajuda muito na interpretação quando você tem grandes transformações. No meu caso, aconteceu uma coisa assim, muito curiosa, pra eu fechar o Floresta das Esmeraldas, porque é o primeiro então tem todo esse destaque. Eu consigo fazer, eu recebo elogios de todo mundo, e percebo a diferença para o meu segundo filme que é Ele, o boto, porque aí eu decido ser atriz, era como se ali eu tivesse fazendo um test drive, chiquérrima, fazendo um test drive com a Embassy Picture. Mas, é aí que eu percebo que é um trabalho. Muito nova. E aí eu concluo, no ano seguinte, com 16. Ganho um sweet sixteen do Boorman, que foi muito querido comigo, o tempo todo, muito respeitoso. A gente viaja de Parati para Belém, foram várias locações, teve Ubatuba. Era uma superprodução. E quando eu volto pra Belém, eu tinha uma independência financeira e tenho uma profissão que veio para mim, porque eu queria ser engenheira. Aí eu decido que eu quero saber o que é que tem nessa vida, e decido vir para o Rio. E venho para o Rio com 17 anos. E aí eu entro na CAL, Casa de Artes Laranjeiras, porque eu queria estudar. $E$ aí faço dois meses só de CAL e vem o teste para fazer Ele, o boto, do Walter Lima Junior. No Walter Lima, a gente teve uma preparação incrivel com a Angel Vianna. Muito o corpo respondendo aos estímulos dos sons. O [Carlos Alberto] Riccelli teve uma coisa mais preparada para aquele corpo de peixe que ele ia ter que ter. $E$ eu, mais uma vez, a caiçara. $E$ aí eu vejo que eu tenho uma respiração, e começo a perceber o que era a respiração. $E$ que as minhas emoções estavam aqui, quando você começa as suas emoções estão todas aqui, depois você aprende e você expande e você sente que sua voz sai daqui, a sua voz de teatro. Quando eu vou para o teatro eu entendo o que é a voz, o que é a projeção, não tem microfone.

Aí eu já era uma mocinha com namorado, já tinha me apaixonado. Então, começando a virar uma mulher. [...] eu acho que tem um desabrochar, admito que eu fui mulher acho que com 24 anos de idade, mais tarde. E ali eu percebi a questão da respiração, e para mim, o Walter (Lima Jr.), diferente do Boorman, o Boorman também tinha um tempo de direção que não tinha nada agoniado, ele era muito calmo e falava olhando nos olhos. Tinha que prestar atenção em muita coisa, não tinha vídeo assiste né, não tinha celular, como se fazia filme, eu não sei. E aí o Walter não falava sobre a cena, especificamente, ele contava uma história sobre alguma coisa. $E$ você falava: "ah meu deus, daqui a pouco a gente vai filmar e esse homem tá falando 
disso agora", contava como se a gente tivesse vendo o filme, sabe? Aquela pessoa que conta a história já editando as imagens e você conseguindo acompanhar. Mas, geralmente, eram coisas que pareciam não ter a ver. No final, quando ele concluía a história e você falava "caraca... Entendi tudo"! Era assim que ele dirigia.

\section{E como que era a preparação? Quanto tempo dessa preparação? Quanto tempo de ensaio?}

Foi com a Angel Vianna. E os ensaios foram muito voltados para o corpo. O texto não entrava. Tinha umas leituras de roteiro, não estou lembrando especificamente de ensaio de cena. A cena em si, ela não era ensaiada. Era ensaiado o corpo, o clima, as improvisações.

\section{E isso você sente que se repete nas suas experiências posteriores no cinema} brasileiro, e essa preparação mais longa e voltada primeiro para o corpo e depois para a cena, isso foi uma constante na sua carreira ou foi ali uma sorte de estrear com diretores que viam assim?

Não. Aí começa um volume de trabalhos, muitos trabalhos estrangeiros, que a gente não tinha ensaio. Nem preparação, você era convidado. E aí termina a Embrafilme, eu vou para a UNIRIO, porque eu percebi assim: eu quero ter um diploma, meus irmãos todos têm, eu quero estudar cronologicamente. Porque eu fazia todos os cursos que apareciam, eu fiz uma preparação autônoma, independente, da minha própria experiência e das possibilidades que eu tinha. Se eu via um curso atraente eu fazia. Sem perceber que eu estava fazendo o melhor por mim nesse momento. $E$ isso teve mais intensidade quando eu entrei na faculdade. Quando acaba a EMBRAFILME em 1990, eu entro na faculdade, começo a fazer um estudo cronológico da História do Teatro, I, II, III e IV. História da Arte, I, II, III e IV, ballet, folclore... A universidade foi muito boa para mim, e os cursos paralelos, eu queria ser... Aí eu já estava achando eu iria ser professora. Porque eu achava, já nessa época, eu olhava a televisão e não me sentia no espelho. Eu não via ninguém parecido comigo e eu falava: "eu não vou pedir nunca um papel, porque vão me dar um papel de servir cafezinho e eu não acho isso justo". Eu só via essa semelhança por causa da "morenice" não permitia você ser um... até hoje é um pouco difícil isso, furar esse bloqueio, é bem difícil. Então eu nunca fui na Globo, pedir para fazer novela ou fazer nenhum papel. Eu já tinha essa empáfia! (Risos). É que quando você pede, você tem que aceitar o que te dão. Aí depois na verdade eu entendi que você não pede, você oferece um trabalho. Mas se você vai lá oferecer o seu trabalho você está restringindo também as ofertas. Eu tive a chance, como eu acho que a segurança financeira me deu, não era de luxo, mas era de ter um... eu não morava de aluguel. Eu não tinha que pensar no aluguel, que já era uma grande coisa. Eu acho que quando eu falo de independência eu acho que é isso. 


\section{Você falou que depois você passa por trabalhos estrangeiros que não tinham ensaio, nem preparação.}

Foi no final da década de 1980, que tinham muitas produções, televisão... Final da década de 1980 é muito diferente do início da década de 1990. Porque tinha muito volume de trabalho.

\section{E no Brasil, na década de 1980 e 1990, como era? Tinha preparação? Tinha ensaio? E quando tinha como era?}

Só para os filmes onde você tem personagem. Importante. Quando tinha era como eu te descrevi, era um trabalho voltado para a leitura do roteiro, vamos dizer um trabalho de mesa, mas, principalmente, um trabalho de corpo, não necessariamente voltado para o personagem, mas voltado para o seu relaxamento, para que você ficasse tonificada, forte, para fazer a cena. Não que aquilo fosse uma descoberta que a gente vai chegar na década de 1990 com esse perfil, né. No Brasil eu via muito assim, eu começo a fazer teatro, eu sei que teatro não faz parte da sua tese, mas, eu faço teatro justamente nesse 1990, 1991, 1992, 1993, e em 1994 eu sou resgatada para o cinema de novo, aí caio no Corisco e Dadá, do Rosemberg Cariry. E eu e Chico Dias fizemos a nossa preparação, sozinhos, porque o Rosenberg tinha uma frase que ele fala: "eu não precisava preparar vocês, era só vocês irem pro sol quente" já tinham a cara que eu queria, era só dar o texto com o sol quente. Era uma preparação, é como se você não poluísse também, e o Corisco e Dadá ele me traz pro cinema com um personagem protagonista, com uma memória, a Dadá foi uma memória do cangaço, então ela descrevia o perfume da roupa que tava usando no dia ... Eu e Chico fomos para a Biblioteca Nacional, o Chico é uma pessoa muito importante na minha vida porque ele me conheceu quando eu tinha terminado de fazer o Floresta e falou: "Vá para o Rio, você é atriz, o que você precisar fale comigo". E ele foi uma pessoa muito legal comigo e isso sem envolvimentos amorosos, que é raro, né? Amigos. Que é importante você perceber que conta com pessoas porque você tem uma humanidade que se afina com eles, né? Não porque você é bonita, porque você é charmosa, porque você tem uma bunda grande, enfim. E aí, Chico... nós vamos para a Biblioteca Nacional e a gente faz uma pesquisa de livros. Isso geralmente vem pronto hoje em dia. Então, eu estar com o Chico, conversando, caminhando, indo até a Biblioteca, pedindo os livros, separando, xerocando, lendo, discutindo, olha que preparação incrível! Aí a gente chega lá no sertão, de Exu. Meu pai, minha mãe, minha avó, minha tia, onde tinham aquelas famílias que se matavam e a casa, a gente foi para a casa do Gonzagão (Luís Gonzaga). Ele não morava mais na casa, era pousada e ele já tinha falecido, inclusive. Mas as pessoas estavam lá ainda [...] aí a temperatura e o figurino... E, no filme, eu envelheço 25 anos, então eu começo o filme com 15 e chego no final, quando o Corisco é abatido pela volante, ela tem quase $30 \ldots$ Mais de 30 até, mais... E ali, por exemplo, em Corisco e Dadá, nessa retomada do cinema brasileiro, a gente foi na contramão, porque era uma retomada e uma época que não era muito charmoso fazer o filme. Na retomada, depois do sucesso da retomada, é que os atores começaram a querer fazer cinema, os atores famosos. Mas de certa 
maneira, o cinema tinha o seu casting, tinha o seu elenco, e eu senti que começa ali um processo de preparação, onde o preparador, ele dita as regras, no sentido que eu vou dizer, se apropriando um pouco do que o teatro faz com a gente naturalmente, que assim, é uma destruição do seu ego, é muito, no teatro não dá para começar a fazer teatro sem zerar o seu ego e começar do zero. No cinema eu não tinha visto isso ainda, o diretor vai se afastando do ator, o preparador se aproxima, o diretor começa a ter video-assist, essa distância fica maior ainda, e o preparador vira uma referência se esta bom ou se esta ruim.

\section{Então na década de 1990, você acha que começa aí?}

Começa. Eu não tive essa experiência de cara não, eu começo a ter essa experiência um pouco mais tarde.

\section{A função do preparador você começa a identificar na década de 1990? Existe essa função mais definida?}

Hoje ela é sine qua non, não era, tinham filmes e filmes. Como eu fiz esse, como eu fui fazer Anahy, de las missiones, que é o meu segundo filme da retomada, e é Rio Grande do Sul, é outra história. E ali a preparação foi feita um pouco parecida com Corisco e Dadá, as roupas ditaram. A gente tinha um acompanhamento, mas não tinha um protagonismo do preparador de elenco, como muitas vezes sequentemente eu vi atores agradecendo os seus prêmios aos preparadores. No final da década de 1990, tipo, começo de 2000, eu também vejo isso muito forte nessa época. Eu não tinha tido ainda contato com esse preparador protagonista. Os filmes sequentes eram voltados mais para uma habilidade específica, tipo o meu personagem toca violino, então eu ia fazer aula de violino, leitura de roteiro... aí para a gente dá um salto, depois a gente pode voltar, se for o caso, eu acho que eu fico nesses trabalhos sem um figura de protagonismo do preparador até 2005.

O que você se lembra do Anahy, até 2005, mais ou menos, é que não tinha esse protagonismo, pelo menos na sua história...

Na minha história não, mas já tinha a Fátima4.

Sim, a Fátima começa com o "Pixote", em 1980 e poucos.

E a Fátima faz Brincando nos Campos do Senhor.

Dez anos depois.

Dez anos depois...

${ }^{4}$ Referência à Fátima (Toledo), preparadora de elenco de inúmeros filmes do cinema brasileiro. 
Ela ficou dez anos trabalhando num banco porque não tinha trabalho para ela.

E provavelmente fazendo outro tipo de trabalho. E depois eu faço um teste com ela para o Brincando nos Campos do Senhor, só que o (Hector) Babenco me achou muito bonitinha, índia para inglês ver... Ele dizia (Imitando o Babenco): Dirinha, não vai dar... (risos)

E porra, eu choro toda vez que eu lembro, que eu queria muito ter feito esse filme. Eu amo muito esse filme apesar de as pessoas não acharem que é um bom filme, muita gente acha que é o filme...

O processo de pesquisa também é uma construção, né? A gente tem hipóteses e aí é claro que quando a gente entra realmente em contato com a pesquisa, você vai confirmando se essas hipóteses são verdadeiras ou não. Então, muitas coisas que eu estou pensando, talvez quando eu entre em contato com vocês eu diga: não, isso aí eu estou achando que é, mas não procede. Por isso é muito rico ouvir vocês. Tem uma distinção que eu faço na minha tese, que aí não é uma hipótese, na verdade é uma distinção que eu acho interessante de trabalhar e eu queria ver o que você acha sobre isso. Que é assim, uma coisa é a preparação de elenco. Ter um preparador. As pessoas me perguntam: "Mas você está fazendo uma tese sobre a preparação de elenco"? E eu digo: Não, eu estou fazendo uma tese sobre a inclusão do ator no processo preparatório da pré-produção. Porque eu como diretora, como amiga de muitos atores, como roteirista, tendo sempre estado envolvida com cinema em todos lugares todos que eu morei e também como professora, o que eu sempre escutei foi assim: "Poxa vida, todo mundo prepara, e eu que sou ator chego na semana anterior e tenho que fazer lá o meu negócio". E o que eu vejo, que eu comecei na retomada né, e quando eu comecei a ver esse processo de ensaio surgindo, pra mim foi assim: "Mas é disso que eu estou falando, que eu sempre defendi. Deixar os caras ensaiarem, deixar a gente ensaiar com eles e pensar o filme em cima disso e tal. Então assim, uma coisa é preparação de elenco, outra coisa é: pode ter preparador, pode não ter preparador, pode ser o diretor que conduz, mas assim, você sente que essa abertura para um tempo maior de ensaio, ela muda? Que agora tem um tempo maior dedicado ao trabalho do ator antes do filme, do que antes?

Eu acho que agora todo o diretor quer um preparador, se puder ter. Salvo a velha guarda da Portela, que trabalham muito bem sem preparador, como Cláudio Assis.

Mas tem ensaio? Não tem preparador, mas tem tempo dedicado a isso, ou não?

Eu chegando de Lua Cambará, sertão, segundo filme com Rosenberg Cariry, indo fazer o: não, não é o Baixio das Bestas, é o Amarelo Manga, indo fazer o Amarelo Manga. Fui direto, do Ceará para o Pernambuco. Já estavam filmando e eu chego para filmar, e fiz prova de figurino. Prova de figurino é muito importante, né? Fiz a prova de figurino, subi o alto o Zé do Pinho, que era onde eles estavam filmando, era 
um domingo, cheguei lá de figurino. Ele gostou do figurino, aí ele falou (imitando o falar de Cláudio Assis): "vá até ali, vá até ali" (risos). Aí eu fui (risos). "Não, não é isso é não: vai lá e volta de novo". E aí Cláudio Assis manda eu ir, né? Aí eu volto, ainda não é assim. Aí ele manda eu ir de novo. Eu estava andando onde o meu personagem morava, sob os olhos do diretor, no intervalo entre uma cena e outra, porque estavam montando a câmera em outro lugar e ele estabeleceu qual era o meu andar. Essa foi a preparação para o Amarelo Manga.

\section{O Cláudio Assis é famoso por isso, eu me lembro de ler uma entrevista grande do Matheus (Nachtergale) também falando...}

O Cláudio, ele confia muito... porque que ele estava tranquilo? Porque ele observou muito o ator que ele queria para o personagem. Tudo que sai de você serve e tudo que ele não quer, ele sabe que ele não quer. Saber o não é muito importante, porque o sim aí pode ser tudo, você sabe o que você não quer e o resto vira numa cartela de possibilidades, aí você escolhe uma. Não que seja fácil também.

Esse período que você me fala, na década de 1990 que foi desde o Anahy até - Amarelo Manga, não tinha muita preparação? Não tinha preparador, mas tinha ensaio? Como é que os diretores e os atores faziam esse trabalho?

Nesse período eu fui muito autodidata. Não. Os diretores às vezes faziam um trabalho de mesa, leitura, e a Betse (de Paula) não teve preparação também. A Betse fez uma coisa muito legal, ela fez uma coisa que eu não tive essa experiência de novo, por ser a minha primeira comédia, porque quando a gente tá falando de filmes existencialistas, você tem um amparo muito grande do que já tá proposto, do que já está escrito, do que é, do que é o figurino, e isso já te dá um estofo, que se eu fosse inglesa, amor, eu nem ia interpretar, só levantava a sobrancelha, né (?), que eu não tenho esse domínio. (Risos). Eu quero fazer um curso de domínio da sobrancelha. É isso que eu vou aprender, porque amor, eu vou ficar tipo. Eu só vou fazer assim ó. (Levanta uma das sobrancelhas). Os ingleses só fazem isso, né (?) e fica chiquérrimo, nos closes e tal. A Betse montou e fez um plano de filmagem cronológico, para o Casamento de Louise. Ela montava o filme, no final do dia, aquela montagem, vamos dizer assim, bruta né, porque era só uma emenda de cenas, mas a gente via se funcionava a piada, porque no final do dia ela assistia com os assistentes, e a gente ria, e era batata. Piada e comédia é muito mais difícil do que o drama, nesse sentido, acho muito mais difícil você fazer uma comédia, do que você fazer um drama, porque você tem a piada como resposta, você quer, você quer a gargalhada. Essa ação que ela teve, ela ia me dando certeza, e aí eu ia ficando cada vez mais segura e dona do meu pedaço. $O$ tipo e os ritmos que estavam sendo propostos. Então você tem o diretor apostando também que ele acertou no ator. O que você tem entre a retomada e ali 2004 até [...] vamos dizer, 10 anos de retomada, você tem os diretores confiando muito nos seus atores. Porque as preparações ou eram para habilidades específicas, mas elas não eram especificamente o tom, o caminho. Também não tinha essa coisa que a gente tem hoje, que o preparador ele não prepara só a mim né, ele prepara o conjunto, 
então ele vai dando os limites. Confesso para você que é quase como você... de certa maneira, incomoda um pouco, porque você perde muito da sua autoria, e da sua autonomia. Você já tem um crivo de qualidade, de qualidade não, de vertente... Antes de chegar no diretor. Esse caminho pode ser um caminho da perdição também. Da perda da autenticidade, da espontaneidade, do insight, o medo de dar um insight cênico e aquilo fugir das balizas. Agora, eu sou atriz mesmo porque eu gosto de ser dirigida. Se vem uma pessoa chata me dirigir, aquilo não vira um perrengue, vira tipo um desafio, que tem gente chata né? O que me provoca uma comoção nessa fase, principalmente a virada do ano 2000, é que eu começo a ver um volume de filmes com não-atores, e aí eu Dira, ralando para fazer bons personagens, pra não ser repetitiva, porque meu desafio como atriz no cinema, era ter uma diversidade, que graças ao meu tipo que antes eu achava que ia me prender, foi libertador porque eu faço filme no Brasil inteiro, o que era libertador...

E aí... os não atores fazendo coisas.... Narradores de Javé quando eu assisti, eu falei: "não, eu vou largar a profissão". Porque se o não-ator faz desse jeito é muito melhor que os atores. Era muito bom, uma espontaneidade, uma apropriação, e eu assim uma pessoa vivida, que tinha passado. Falei: caraca, me emocionava muito mais, aí você um ator interpretando e vê aquele não-ator poderoso.

\section{E esses não-atores tinham preparação?}

Eu fui descobri que esses não-atores não tinham nada de não-ator. Era João Miguel, falei porra. Aí vem a frase do Mocarzel, que eu amo, ele fala: “Dira, se um não-ator pode, porque tinha os não-atores, no Narradores de Javé, tem não-ator à beça, e foi incrível. Eu não fiz o filme, mas eu sei que tinha preparação. [...] a minha mãe, foi a Lucy Pereira, no Velho Chico. Ela é atriz do Narradores de Javé, e ela é atriz de teatro na Paraíba, estava no meio dos não-atores. Então essa mescla é ela muito positiva também. Que nem eu em Dois filhos de Francisco, contracenando com 20 crianças maravilhosas, e você com medo de estragar a cena com as crianças maravilhosas. Então, aí a frase do Evaldo, que é maravilhosa, "se um não-ator pode, um ator pode muito mais", e aí eu resgato um conforto que realmente é isso. A partir dali eu começo a conviver com a realidade de ter um preparador. A partir de 2005 isso vira uma instituição, para mim né, não que isso já não tenha... E o preparador acaba sendo aquele que tem o contato que eu falo assim, com o cristalzinho. Não todos os diretores, os diretores mais sagazes, é difícil fazer comparação, porque isso não quer dizer que vai ser qualidade, tem a ver com o seu prazer de processo, de certa maneira o preparador tem um contato com o seu cristalzinho, é ele que tem e eu acho tão bom quando é o diretor que tem esse contato com o cristalzinho. Agora um preparador, quando você está falando de um elenco, ele realmente assume funções muito nobres. E de certa forma algumas experiências são ótimas para não se repetir nunca mais. 
Vou te fazer duas perguntas para fechar. A primeira é: $O$ que você acha que muda, uma vez que se instituiu a figura do preparador, e antes dele?

Eu acho que muitos diretores não têm esse prazer, e eu acho que quando o diretor tem esse prazer é muito melhor. Porque tem que ter prazer para fazer isso. $\mathrm{E}$ talvez a habilidade também.

Você percebe alguma mudança na relação com a equipe? Na relação com o diretor? Na maneira como o diretor decupa?

Eu percebi muita diferença com o vídeo-assist. O vídeo-assist nos afastou muito da equipe, e do diretor. Eu tenho muita agonia de ouvir: "ação" da boca do assistente, o "ação" vinha da alma do diretor. O diretor agora não fala mais "ação", é o assistente. Pequenas mudanças que nós somos automatizados, então o diretor fica lá na cabine: "Vamos fazer outra"... Muita gente corre para assistir, eu não gosto de assistir porque você para uma coisa para ir assistir, isso também tão mudando. Não tão mais fazendo isso de deixar... eu sinto que o diretor, ele meio que delegou os atores, não a maioria, mas eu sinto.

\section{Depois da instituição do preparador de elenco?}

É, mas como se ele fosse mais habilitado para lidar com os atores. E por isso...

Essa coisa de preparador de elenco é muito louca né, porque é uma instituição, mas ainda é uma profissão meio invisível para quem está de fora. Eu, na minha pesquisa, vou buscar esses nomes, e aí tem filme que eu acho que tem preparador, tenho quase certeza que tem preparador, eu jogo aquilo ali no google, acho o filme, e não vejo o crédito da pessoa. As vezes eu tenho que baixar o filme, para esperar até o crédito final, para achar o nome dessa pessoa. Nessa linha de raciocínio, você poderia citar, e eu não estou perguntando quem você gostou mais ou quem você gostou menos, nada disso. Você poderia citar nomes de preparadores com o quem você trabalhou?

Eu acho que tem algumas questões nisso. Um preparador, por exemplo, que é apaixonante, e que todos nós amamos, porque ele tem o tom é o Chico Accioly. $O$ Francisco Accioly, ele sabe lidar com esse ator que... A Laís, que não vou lembrar o sobrenome dela, que fez Dois filhos de Francisco, porque esse preparador quando, você tem o encontro desse preparador com crianças se torna fundamental. Com não-atores, com estreantes. Agora esse preparador que está te preparando, um ator mais experiente que tem o caminhar dele, ele tem que ter o maior cuidado para não atrapalhar. O Zé Luiz Villamarim, do Redemoinho, e Chico Accioly, eles vêm de uma parceria muito grande, o Francisco Accioly, que aí a gente chama de Chico Accioly. Eu destacaria ele como o grande preparador do momento. Porque ali tem uma parceria de olhar muito grande, e que não é nada impositiva. Tudo aproveitando o que nós atores podemos dar, e que não é, que nos tira, por exemplo, aquele olhar de quem 
conhece o seu trabalho e sabe que você tá num lugar de conforto, se você tá tendo um olhar errado para o seu próprio trabalho, então, tem uma coisa assim... Eu acho Virgínia, que esses preparadores, quando tem... e tem muitos diretores, acho que você não acha, porque tem muitos diretores que se constrangem um pouco de usar, de ter essa presença de alguém, que na verdade fez um trabalho, que era um trabalho muito voltado para esse diretor, geralmente esse diretor estava assessorado por pessoas que iam fazer preparação corporal, e não uma preparação intelectual do trabalho. E tem muita gente também hoje em dia, já se sente confortável, é o contrário, impõe ao diretor o preparador. Eu gosto mais da minha relação com a direção, e acho que o preparador é um condutor do seu talento de alguma maneira. Agora, é muito difícil e gosto da ideia dessa pessoa quando a gente vai para o conjunto, quando vai todo mundo para a cena. Agora, individualmente o grande preparador, ele não interfere na autenticidade da sua criação, ele deixa o ator voar. E o que a gente vê é que hoje em dia em alguns trabalhos, a insegurança é tão grande do diretor em relação às cenas que ele se abstém da direção cênica, eles acabam absorvendo uma direção técnica. Ao mesmo tempo, por exemplo, eu acabei de fazer uma preparação, quer dizer, acabei de fazer Órfãos do Eldorado, quem fez a preparação? Tadashi Endo, o grande dançarino de Butoh, e nós fizemos uma preparação de dois dias, e ele me olhou e me falou: "eu não quero fazer mais nada com você, tá tudo certo". A gente fez um improviso, que aí eu fiquei com a sensação, já acabou...? Quero mais. Não, ele não queria fazer mais nada comigo. Ele, a gente teve um improviso, ele mandou eu repetir, você vê como a gente precisa de um olhar, e o Guilherme foi muito delicado nisso, ele falou: "agora você entra na casa de novo, mas saiba que o dono da casa está nessa sala aqui". E quando eu fiz a coisa, ele foi muito especial. Eu espero que a tendência realmente é o preparador estar ali, e acaba que o preparador é um diretor artístico não reconhecido.

\section{E nesses filmes que você fez com preparadores, ficam sempre na cena, na filmagem ou só anterior?}

Não, o Tadashi, por exemplo, não. O Chico fica. O Chico é o cara. Eu acho que quando realmente tem uma condução do preparador durante todo o processo ele fica em cena, não é um preparador, é contínuo, é um trabalho contínuo, é um diretor de elenco, e acho que de certa maneira, diretor artístico, e isso é muito notório.

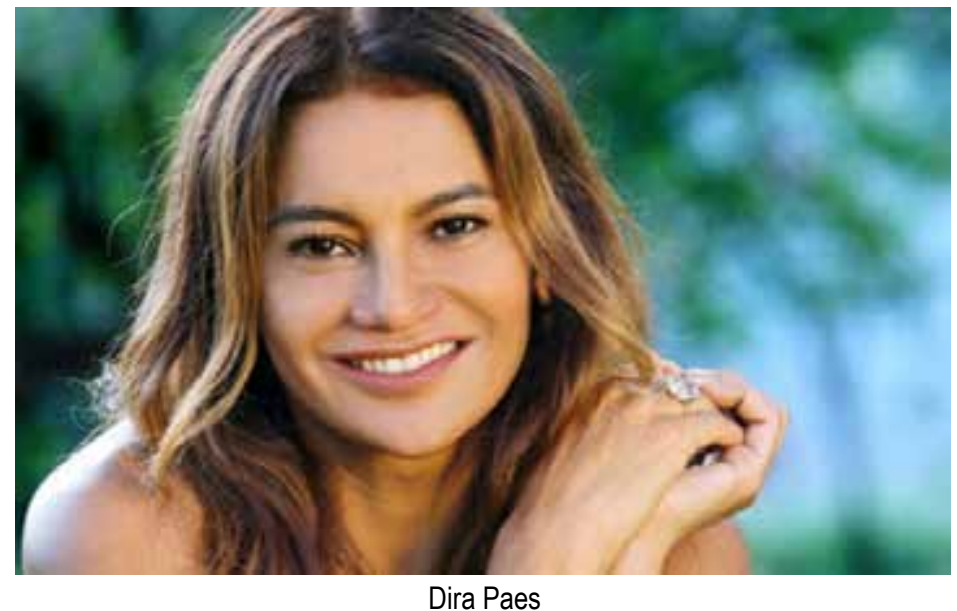

https://www.otvfoco.com.br/dira-paes-aparece-beijando-o-marido-em-foto-rarissima-da-vida-particular/ 


\section{Referencias Filmográficas}

The Emerald Forest. Direção: John Boorman, 1985.

Ele, o Boto. Direção: Walter Lima Jr., 1987

Tainá - Uma aventura na Amazônia. Direção: Tânia Lamarca e Sérgio Bloch, 2000.

Tainá 2 - A aventura continua. Direção: Mauro Lima, 2004.

Tainá - A origem. Direção: Rosane Swartman, 2013.

Corisco \& Dadá. Direção: Rosenberg Cariry, 1996.

Anahy de las Missiones. Direção: Sérgio Silva, 1997.

Pixote. Direção: Hector Babenco, 1981.

Brincando nos campos do senhor. Direção: Hector Babenco, 1991

Lua Cambará: Nas escadarias do palácio. Direção: Rosemberg Cariry, 2002.

Amarelo Manga. Direção: Cláudio Assis, 2003.

Baixio das bestas. Direção: Cláudio Assis, 2007.

O casamento de Louise. Direção: Betse de Paula, 2001.

Narradores de Javé. Direção: Eliane Caffé, 2003.

2 Filhos de Francisco. Direção: Breno Silveira, 2005.

Órfãos do Eldorado. Direção: Guilherme Cezar Coelho, 2015

Redemoinho. José Luiz Villamarim 2017.

Recebido em: 14/03/2018

Aprovado em: 15/05/2018 